\title{
ALLEVIATING AN ACID SULFATE SOIL CULTIVATED TO RICE (Oryza sativa) USING GROUND MAGNESIUM LIMESTONE AND ORGANIC FERTILIZER
}

\author{
Totok Suswanto, J. Shamshuddin*, S.R. Syed Omar, Peli Mat and C.B.S. Teh
}

\author{
Department of Land Management, Faculty of Agriculture, Universiti Putra Malaysia, 43400 Serdang,
} Selangor Malaysia

\begin{abstract}
Rice yield on acid sulfate soils in Malaysia is very low, presumably due to Al and/or Fe toxicity. This study was conducted to ameliorate an acid sulfate soil in the Kemasin-Semerak Integrated Agricultural Development Project, located in Kelantan, Peninsular Malaysia, for rice cultivation. Rice variety, MR 219, was used as the test crop. Treatment included the use of various rates of ground magnesium limestone (GML), with or without an organic fertilizer. This acid sulfate soil had an initial pH of $<3.5$ at depth below $45 \mathrm{~cm}$. Exchangeable Al in the soil was high, especially in the subsoil. The first crop of rice was disturbed by floods. The result for the $2^{\text {nd }}$ crop showed a promising trend; applying $4 t$ GML/ha in combination with an organic fertilizer, the topsoil $p H$ had increased from 3.95 to 4.21, increasing the exchangeable $\mathrm{Ca}$ and $\mathrm{Mg}$ from 1.58 and 0.48 cmol $/ \mathrm{kg}$ soil to 2.57 and $0.79 \mathrm{cmol} / \mathrm{kg}$ soil, respectively. In this treatment, the rice yield was $7.5 \mathrm{t} / \mathrm{ha}$, which was much higher than that produced by farmer's practice of about 2 tha. The increase in yield was due to the combined effects of increasing $p H$ and exchangeable $\mathrm{Ca}$ and $\mathrm{Mg}$ and of lowering $\mathrm{Al}$ and Fe concentration in the soil solution.
\end{abstract}

Key words: Acid sulfate soil, Rice, Limestone, Aluminum, Iron

\section{INTRODUCTION}

The Kemasin-Semerak Integrated Agriculture Development Project (IADP), comprising total area of 68,350 ha, was launched by the Ministry of Agriculture Malaysia in 1982, with the support of the Kelantan State government. The project area is located in the so-called Kelantan Plain; Kelantan is an east coast state of Peninsular Malaysia (Figure 1). The Kelantan Plain is in the tropical wet climatic zone, with a mean daily temperature of $32^{\circ} \mathrm{C}$ and a mean annual rainfall of $2290-2540 \mathrm{~mm}$ (Ooi, 1964). The climate is influenced by the South China Sea during the Northeast Monsoon, which is from November to January.

The plain is characterized by the presence of a mixture of riverine and marine alluvial soils, formed as a result of the rise and fall in sea level since the Quaternary (Djia, 1973). Peaty materials sometimes overlain by mixed clayey-sandy sediments occasionally with variable amounts of pyrite are scattered all over the plain, especially along the coastline. This eventually gives rise to development of acid sulfate soil conditions, which are harmful to crops growing on the soils, especially rice.

With a population of about 250,000 from more than 40,000 households, about $80 \%$ of the people involve in farming activities, particularly rice production.

Unfortunately, some of the soils in the rice farms are too acidic (acid sulfate soils) for rice cultivation, with soil $\mathrm{pH}$ frequently less than 3.5. When this occurs, $\mathrm{Al}$ and $\mathrm{Fe}$ contents in the solutions are usually very high. This is particularly true at spotted locations in the Jelawat ${ }_{\text {Rusa }}$

\footnotetext{
* Correspondence: J. Shamshuddin, Department of Land Management, Faculty of Agriculture, Universiti Putra Malaysia, 43400 Serdang, Selangor, Malaysia. Fax: 603 9434419;

E-mail: samsudin@agri.upm.edu.my
}

Irrigation Scheme, which are about 1384 ha in size. Rice yield in the scheme varies from to year, but always remain within the limit of 1.29 and 3.06 tha. The acid sulfate soils in this area belong to the Nipis-Bakri Associations (peat soils) of the Malaysian Soil Classification System. Some the rice fields having this soil infertility problem have been abandoned by the farmers.

Normally, acid sulfate soils are not suitable for crop production. Unless they are properly ameliorated using current technology in agronomic practices, the soils are not for agriculture use. Among the agronomic problems common to acid sulfate soils are toxicity due to the presence of $\mathrm{Al}$, decrease on $\mathrm{P}$ availability, nutrient deficiency, $\mathrm{Fe}(\mathrm{II})$ toxicity and plant stress due to the presence of sulfuric horizon (Dent, 1986).

The activities of $\mathrm{Al}^{3+}$ in the soil solution are controlled by $\mathrm{Al}(\mathrm{OH})_{3}$ (gibbsite) but only at high $\mathrm{pH}$. Thus, raising the $\mathrm{pH}$ would render the $\mathrm{Al}$ inactive, as gibbsite is inert. $\mathrm{Al}$ in soil solution at $1-2 \mathrm{mg} / \mathrm{kg}$ can be toxic to rice (Dobermann and Fairhurst, 2000). Soluble Al accumulates in the root tissues, preventing cell division and elongation (Rorison, 1973).

In the presence of organic material, Fe(II) toxicity may occur due to the subsequent reduction of $\mathrm{Fe}(\mathrm{III})$ under flooded soil conditions (Tran and Vo, 2004).

According to Moore and Patrick (1993) Fe(II) activities were seldom equilibrium with iron solid phases in acid sulfate soils. Ponnamperuma et al. (1973) reported values of $5000 \mathrm{mg} / \mathrm{kg} \mathrm{Fe}$ (II) within 2 weeks of flooding. Iron uptake by rice is correlated with $\mathrm{Fe}^{2+}$ activities in soil solution (Moore and Patrick, 1993). Concentration above $500 \mathrm{mg} / \mathrm{kg} \mathrm{Fe}$ (II) is considered toxic to rice plants planted on acid sulfate soils (Nhung and Ponnamperuma, 1966).

Liming is a normal agronomic practice worldwide to manage acid sulfate soils for crop production. In Malaysia, some areas of acid sulfate soils have been reclaimed for rice 
cultivation using ground magnesium limestone (GML). In the acid sulfate soils of the Muda Agricultural Development Authority (MADA) granary areas in Kedah-Perlis coastal plains (northwest coast of Peninsular Malaysia), for instance, rice yield improved significantly after applying 2.5 tonnes of ground magnesium limestone per ha (Arulando and Kam, 1982). In another area called Merbok Scheme (also in the Kedah-Perlis coastal plains), rice yield increased from 1.4 tha (in 1974) to 4.5 tha (in 1990) after yearly application of $2 \mathrm{t} \mathrm{GML/ha} \mathrm{(Ting} \mathrm{et} \mathrm{al.,} \mathrm{1993).}$

Acid sulfate soils can also be ameliorated, to some extent, by application of organic materials (Muhrizal et al., 2003). Application of organic matter in Al-toxic soils increases yield by detoxification of $\mathrm{Al}$ through $\mathrm{pH}$ increase and complexation of Al by organic matter (Hue and Amien, 1989). The slight increase in soil $\mathrm{pH}$ can be due in part to release of $\mathrm{NH}_{3}$ during decomposition of organic matter as being reported for green manure (Hoyt and Turner, 1975).

The objective of this study was to ameliorate an acid sulfate soil having high contents of organic matter in the at the Jelawat Rusa Irrigation Scheme, Kemasin-Semerak Integrated Agricultural Development, Kelantan Project using ground magnesium limestone and an organic-based (rice husk) fertilizer for rice cultivation.

\section{MATERIALS AND METHODS}

\section{The Location and Soils}

The location of the trial was Jelawat Rusa Irrigation Scheme of the Kemasin-Semerak IADP, Kelantan, Malaysia $\left(06^{\circ} 00 \mathrm{~N}, 102^{\circ} 23 \mathrm{E}\right)$ (Figure 1). The soils in the experimental plots belong to the Nipis-Bakri Associations (organic soils underlain by sulfidic materials with $50 \mathrm{~cm}$ depth), which can be classified as Typic Sulfosaprists. The peaty materials have been somewhat degraded as a result of a long history of rice cultivation. In the soil profile, the sulfuric layer occurs below the depth of $45 \mathrm{~cm}$.

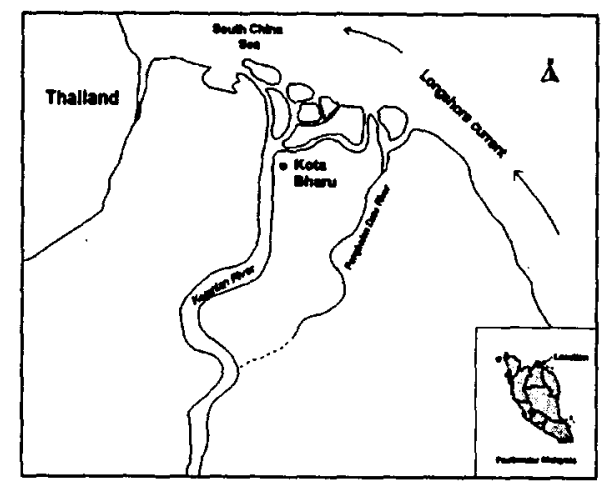

Figure 1. The Location of the Study

Prior to treatment, soil samples were collected at 15 $\mathrm{cm}$ interval to the depth of $75 \mathrm{~cm}$ at selected locations in the experimental plots (T1, T3, T5) in order to determine the initial chemical properties of the soils. Further soil samplings were carried out after every rice harvest for every treatment in the trial, but only for the topsoil $(0-20$ cm depth).

\section{The Rice Variety Tested}

The rice (Oryza sativa) variety used in the trial was MR 219. This is the most common rice variety planted by Malaysian rice growers in the Kelantan Plain. This is a rice variety specially bred for the conditions prevailing in Malaysia, but not necessarily for acid sulfate soils. Record from the past harvest shows that this rice variety yields about 2 tha at the site using farmer's practice, which is below the national average of $3.8 \mathrm{tha}$.

\section{Experimental}

The experiment was laid out in the field using Completely Randomized Design (T1 to T7, see Table 1), with five replications. Next to the experimental plots was a demonstration plot, where rice was grown to show the farming community in the vicinity of the trial the latest in farming technology. No soil analysis was carried out in this area. Here the rice was grown using lime and organic fertilizer according to the rate recommended for farming practice (T6, Table 1). The lime used was ground magnesium limestone (GML) of size less than 100 mesh, with $\mathrm{Ca}$ and $\mathrm{Mg}$ contents of 21.7 and $13.2 \%$, respectively. This rate was used as one of the treatments in the field trial. Each experimental plot size was $3 \times 3$ meters. There were altogether seven treatments. The treatment for the trial included a control (no lime, T1); the rest of the treatments are given in Table 1. The amount of organic fertilizer (rice husk-based) applied was 0.25 tha.

Table 1. Treatment in the Field

\begin{tabular}{cc}
\hline Symbol & Treatment \\
\hline T1 & Control (0 t GML/ha) \\
T2 & 2 t GML ${ }^{+}$ha \\
T3 & 4 t GML/ha \\
T4 & 6 t GML/ha \\
T5 & 8 t GML/ha \\
T6 & 4 t GML/ha + JTU* \\
T7 & 4 t GML/ha + FMP* \\
\hline
\end{tabular}

+ GML - Ground Magnesium Limestone

* JITU - Sugar cane-based organic fertilizer ( 0.25 tha)

\# FMP - Fused Magnesium Phosphate

During the trial, the direction of the water flow was east to west. Water flow was the main concern of the experimental layout. The plots had been designed so as to allow the irrigation water flow from the control to that of the maximum lime treatment $(8 \mathrm{t} / \mathrm{ha})$. The purpose of this design was to minimize the effect of residual lime, which under the circumstances, could be removed by the flowing water.

The main rice season in the Kelantan Plain is November-April, while the off-season is May-September. For this trial, we had planted two successive crops of rice, during the main season. Ground magnesium limestone (otherwise referred to as GML) was applied once in midOctober 2002 and the seeding was done two weeks later, just before irrigation water was allowed to flow into the experimental plots. This dolomitic limestone is the type of lime normally being used in Malaysia. 
We had given standard fertilizer rates to the growing rice plants in the field in Malaysia (90 kg N/ha, $12 \mathrm{~kg} \mathrm{P} / \mathrm{ha}$, $90 \mathrm{~kg} \mathrm{~K} / \mathrm{ha}$ ), using urea, NPK Blue (12:12:17+TE) and NPK Green (15:15:15+TE) as the sources of the nutrients. This rate was for optimal rice growth, which was slightly higher than that using farmer's practice. The organic fertilizer used was sugar cane-based compost. A growth enhancer developed by the Department of Land Management, so named as Vitagrow (containing some micronutrients), was used in the trial to help improve the rice production. Vitagrow was sprayed 3 times on the leaves of the growing rice plants 25,35 and 65 days after sowing.

\section{Soil Analyses}

The soil $\mathrm{pH}(1: 2.5)$ was determined in water. The cation exchange capacity (CEC) was determined using $\mathrm{NH}_{4} \mathrm{OAc}$, buffered at $\mathrm{pH}$ 7. Exchangeable $\mathrm{Ca}, \mathrm{Mg}$, and $\mathrm{K}$ in the $\mathrm{NH}_{4} \mathrm{OAc}$ extract were determined by atomic absorption spectrometry (AAS). Exchangeable Al was extracted by I $\mathrm{M} \mathrm{KCl}$ and determined by AAS. The organic carbon was determined by the standard Walkley-Black method (Wakley and Black, 1934).

Iron in the soils was determined by double acid method (henceforth referred to as acid-extractable $\mathrm{Fe}$ ). It was extracted using $0.05 \mathrm{M} \mathrm{HCl}$ in $0.0125 \mathrm{M} \mathrm{H}_{2} \mathrm{SO}_{4}$. A five-gram sample of the soil was mixed with $25 \mathrm{~mL}$ of the extracting solution and shaken for 15 minutes. The solution was then filtered through Whatman filter paper number 42 before determining the Fe it contained by AAS.

Crop cutting test (CCT) was conducted before each rice harvest. In this CCT, samples in both the experimental and demonstration plots were taken. The rice grain was then clean and dried to have $14 \%$ moisture content. This test was carried out as a second method to determine the rice yield per unit area.

\section{RESULTS AND DISCUSSION}

\section{The Initial Soil Chemical Properties}

Table 2 gives the chemical characteristics by depth of the soils at selected locations of the experimental plots in the trial before treatment. In general, the topsoil $\mathrm{pH}$ was low; the values were even lower at the depth below $50 \mathrm{~cm}$. At the depth of $45-60 \mathrm{~cm}$, the $\mathrm{pH}$ values were lower than 3.5 in all the three locations in the experimental plot (Table 2). This low $\mathrm{pH}$ coinciding with the presence of jarositic mottles in the soils at that depth qualifies them to be classified as acid sulfate soils. According to a study conducted in Vietnam, the depth of jarositic layer in an acid sulfate soil is not related with rice productivity (Husson $e t$ al., 2000).

The low $\mathrm{pH}$ was made even worse by the presence of high exchangeable $\mathrm{Al}$, especially at depth below $45 \mathrm{~cm}$, which were the sulfuric layers. Peculiar only to the soils in the Kelantan Plain, the exchangeable $\mathrm{Ca}$ and $\mathrm{Mg}$ were very low (Soo, 1975). Hence, liming is necessary to supplement the macronutrients.
These soils are considered as Histosols based on the high organic matter contents, present under saturated conditions in most part of the year. The organic carbon in the topsoil of the T5 was $25.6 \%$ (Table 2). On closer examination, it was found that the peaty materials were completely decomposed, and thus could be considered as sapric materials. The CEC (data not shown) of less than 20 $\mathrm{cmol}_{\mathrm{c}} / \mathrm{kg}$ soil further proves that the organic had broken down and completely mixed with mineral sediments. The $\mathrm{CEC}$ of normal organic matter is very high, having a value more than $200 \mathrm{cmol}_{\mathrm{c}} / \mathrm{kg}$. According to the soil taxonomy (Soil Survey Staff, 1999) these soils can be classified as Typic Sulfosaprists due to the presence of peaty materials and sulfuric horizon within the depth of $50 \mathrm{~cm}$. In essence, these are acid sulfate soils having high organic matter contents.

The initial topsoil exchangeable $\mathrm{Ca}$ ranged from 1.17 to $1.68 \mathrm{cmol}_{\mathrm{c}} / \mathrm{kg}$ soil, lower than the required level for rice of $2 \mathrm{cmol}_{\mathrm{c}} / \mathrm{kg}$ soil (Palhares, 2000). The initial exchangeable $\mathrm{Mg}$ was only $0.50-0.53$, but $\mathrm{Mg}$ requirement is $1 \mathrm{cmol}_{\mathrm{c}} / \mathrm{kg}$ soil (Dobermann and Fairhurst, 2000). According to these researchers also, Al concentration of 1-2 $\mathrm{mg} / \mathrm{kg}$ in the soil solution would cause toxicity to the growing rice plants. Potassium contents seemed to be moderately high and thus would be sufficient for rice growth.

Based on the presence of deficient amounts of the two macronutrients ( $\mathrm{Ca}$ and $\mathrm{Mg}$ ), it is appropriate that the infertility of the soils can in part be ameliorated by application of dolomitic limestone, which contains both elements, like we did in this trial.

\section{The Effects of Treatment on Soils}

Flood occurred twice in late November 2002, wrecking havoc on the chemical properties of the soils at the experimental plots. It is not possible to estimate how much damage the flood had caused to the rice production. The soil analyses carried out on the soil samples after the first rice harvest (sampled in April 2003) showed unexpected results. For instance, in $\mathrm{T} 1$, the topsoil $\mathrm{pH}$, exchangeable $\mathrm{Al}$, exchangeable $\mathrm{Ca}$ and exchangeable $\mathrm{Mg}$ were $3.95,5.83,1.06$ and $0.46 \mathrm{cmol}_{c} / \mathrm{kg}$ soil, respectively (data not shown). In the T5, where 8 tonnes/ha of GML were applied, the corresponding values were 4.38, 2.64, 2.86 and $1.21 \mathrm{cmol}_{\mathrm{c}} / \mathrm{kg}$ soil. Ironically, the respective values for $\mathrm{T} 7$ were higher than those of the $\mathrm{T} 5$, where only 4 tonnes/ha of GML were applied. The corresponding values for this treatment were $4.93,0.12,8.60,3.37$ cmol $/ \mathrm{kg}$ soil. This is not to mention the considerable change on other soil chemical properties. All these would be seen in the response of the rice plants shown by the yield of rice in this trial in the $1^{\text {st }}$ season. Fortunately, the effect of this flood on rice yield was less remarkable in the $2^{\text {nd }}$ season. 


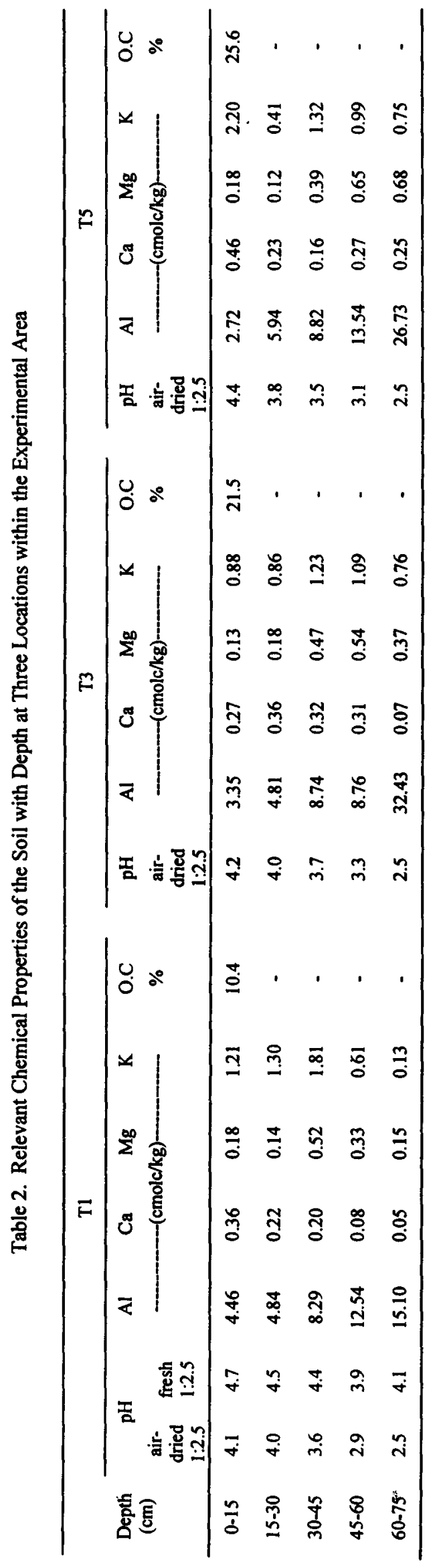


As expected, the results of the soil analyses for the second season (sampled on May 1,2004 ) conformed to the rule. The lowest $\mathrm{pH}$ with a value of 3.95 was reported for the control. The highest $\mathrm{pH}$, being 4.52 , was reported for T5, where the most amount of GML was applied (Table 3). Consistent with the lowest $\mathrm{pH}$, the control treatment had the highest value of exchangeable $\mathrm{Al}$, with a value of 12.75 $\mathrm{cmol}_{\mathrm{c}} \mathrm{kg}$ soil. As a result of the GML application, soil $\mathrm{pH}$ slowly but surely increased, culminating in the T5. In this treatment, the exchangeable $\mathrm{Ca}$ and $\mathrm{Mg}$ were the highest in the trials, having values of 3.74 and $1.10 \mathrm{cmol}_{c} / \mathrm{kg}$ soil, respectively. The increase in $\mathrm{pH}$ was concomitantly followed by the lowering of exchangeable $\mathrm{Al}$ in the soil, the value of $\mathrm{Al}$ being $2.37 \mathrm{cmol}_{\mathrm{c}} / \mathrm{kg}$ soil. This was the lowest value of exchangeable recorded for this trial.

\section{Rice Yield in the $1^{\text {st }}$ Season}

The two floods of November of 2002 had somewhat affected the growing rice seedlings such that after the floods, some plots needed to be reseeded (by transplanting). There could also be removal of the some liming materials by the running water during the height of the flood period; each flood lasted for about a week. The effect of the flood is clearly seen in the erratic values of the rice yield (Table 4). There seemed to be no real difference in rice yield between treatments. Note that the highest yield was seen on $\mathrm{T} 2$, where $2 \mathrm{t}$ GML/ha was applied. But this yield was not significantly different from the control. The result of the trial for the $2^{\text {nd }}$ would be presented later.

Seeding of the $1^{\text {st }}$ planting season was done two weeks after lime treatment. This is considered a long enough for the lime to react with soil, given the acid soil conditions at the site. The rice yield for the recommended rate (T6) was $3 \mathrm{t}$ /ha; this was lower than that of the control though it was significantly no difference.

\section{Rice Yield in the $2^{\text {nd }}$ Season}

The highest rice yield for the $2^{\text {nd }}$ season was 7.5 tha obtained by $\mathrm{T} 6$ (Table 4). For this treatment, we had applied $4 \mathrm{t} \mathrm{GML/ha}$ in combination with $0.25 \mathrm{t} / \mathrm{ha}$ rice husk-based organic fertilizer (JITU). This yield is comparable to the yield of rice grown on good soils in the granary areas of the west coast of the peninsula. Note that the national average for Malaysia is only 3.8 tha.

It was observed that the yield obtained by $\mathrm{T} 6$ was not significantly different from that of the T3, T4 and T5. There was indication that applying $2 \mathrm{t} \mathrm{GML/ha} \mathrm{(T2)} \mathrm{is} \mathrm{not} \mathrm{enough}$ to ameliorate the soil for rice cultivation. As Table 3 shows, for the $\mathrm{T} 2$, the $\mathrm{pH}$ was still low (3.99) and Al was very high (10.22 $\mathrm{cmol} / \mathrm{kg}$ soil). For T7, where $4 \mathrm{t} \mathrm{GML/ha} \mathrm{were}$ applied in combination with fused magnesium phosphate, the yield was not significantly different from that of the T6. It means that instead of using organic fertilizer, farmers in that area can apply lime together with fused magnesium phosphate. The Malaysian government gives farmers in the Kelantan Plầin this kind of phosphate fertilizer as a form of subsidy to increase rice production.

The result of the CCT on the demonstration plot agreed well with that of the experimental plot. It obtained a yield of $7.6 \mathrm{t}$ tha. We know that this is way above the national average of 3.8 tha. Rice grown on the demonstration plot was for real. It was grown on almost half a hectare field, which is a normal paddy field size in the Kelantan Plain. Note that the demonstration plot followed the T6 treatment. This treatment is indeed very promising and can be used for recommendation to the rice farming community at the Jelawat Rusa Irrigation Scheme.

\section{General Discussion}

\section{Ca and Mg Deficiency}

The presence of large amounts of $\mathrm{Ca}$ in soils is good in itself. It is by nature that $\mathrm{Ca}$ is, to a certain extent, able to reduce the toxic effect of Al (Alva et al., 1986; Shamshuddin et al., 1991). This would happen from T3 right to $\mathrm{T} 7$ (Table 3). The amelioration of Al toxicity, should there be any, would be shown by the increase in rice yield (Table 4). The presence of extra $\mathrm{Mg}$ could also contribute to alleviation of Al toxicity as had been shown by Shamshuddin et al. (1991) for maize.

\section{Aluminum Toxicity}

Aluminum toxicity is a major problem for rice grown on an acid sulfate soil. High exchangeable Al in soil is usually associated with low $\mathrm{pH}$. This is clearly shown by the data given in Table 3; the lowest $\mathrm{pH}$ coincides with the highest Al (T5). It shows the opposite in T1. As seen in Table 1, the initial exchangeable Al was extremely high in some samples, reaching a value of $32.43 \mathrm{cmol} / \mathrm{kg}$ soil in the subsoil of $\mathrm{T} 3$. The lowest value was 2.72 , in the topsoil of T5. In the water in the vicinity of the experimental plots, Al would certainly exceed the critical value for rice production of $1-2 \mathrm{mg} / \mathrm{kg}$. This high $\mathrm{Al}$ in the solution can be reduced to an accepted level by applying GML at an appropriate rate. This study suggested that GML application at 4 tha would be appropriate.

\section{Iron Toxicity}

One of the most important problems facing production of rice on acid sulfate soils is Fe toxicity. We observed that in the abandoned rice fields, the water was reddish in color, indicating the presence of high amounts of soluble iron. In this study, acid-extractable $\mathrm{Fe}$ in the soils was slightly above the critical level, ranging from 0.07 to $0.81 \mathrm{cmol} / \mathrm{kg}$ soil (data not shown). Critical Fe concentration varies from 0.05 to $5.37 \mathrm{cmol}_{\mathrm{c}} \mathrm{kg}$ soil (Dobermann and Fairhurst, 2000) implying that $\mathrm{Fe}$ may not be the only source soil toxicity that causes reduction in yield.

\section{Phosphorus Deficiency}

Another major problem of cultivated rice on acid sulfate soils is P-deficiency. This is caused by high Pfixation capacity of the soil due to the presence of high amounts of $\mathrm{Al}$ and or Fe. $\mathrm{P}$ is unavailable to the rice and will remain in place where it is applied due to its immobilization. So, once soluble phosphate fertilizer is 
applied, it will revert back to its less or insoluble form. Lack of $P$ in the soil can be somewhat alleviated by applying fused magnesium phosphate (T7).

Lack of available $P$ in the soil would cause stunted growth, reduced tillering and reduction in the number of panicles. In the $2^{\text {nd }}$ season, the available $P$ was about 4 ppm (data not shown), and there was no significant difference between treatments. But the rice yield did not seem to be affected significantly by the possible lack of available $P$ in the soils, as the yield in T6 and T7 had shown. The required soil available $P$ for rice production is 7-20 ppm (Dobermann and Fairhurst, 2000).

\section{The Effects of Organic Fertilizer}

Adding organic fertilizer into a flooded acid sulfate soil would intensify reducing condition, resulting in release of $\mathrm{Fe}^{2+}$, which is toxic to rice plants (Tran and Vo, 2004). Putting organic fertilizer at the rate applied in the current study did not show any effect on rice yield. Treatment T6 in which GML applied together with organic fertilizer gave the highest rice yield of $7.5 \mathrm{t} / \mathrm{ha}$ in $2^{\text {nd }}$ season (Table 4). On the contrary, high quality organic matter, like organic fertilizer used in the current study, would hasten reduction of Fe that result in pH increase (Muhrizal et al., 2006).

\section{Relationship between Rice Yield and Soil Parameters}

The lime (GML) used in this study was dolomitic limestone $\left[(\mathrm{Ca}, \mathrm{Mg})\left(\mathrm{CO}_{3}\right)_{2}\right]$. Adding this lime would increase soil $\mathrm{pH}$ accordingly, with concomitant addition of $\mathrm{Ca}$ and $\mathrm{Mg}$ into the soil. For $2^{\text {nd }}$ season of the trial, soil $\mathrm{pH}$ increased linearly with increasing exchangeable $\mathrm{Ca}$ (Figure $2 A)$, with $\mathrm{R}^{2}=0.73$. Likewise, $\mathrm{pH}$ increased linearly with increasing exchangeable $\mathrm{Mg}$ (Figure $2 \mathrm{~B} ; \mathrm{R}^{2}=0.78$ ).

GML ameliorated in the soil according to the following reactions:

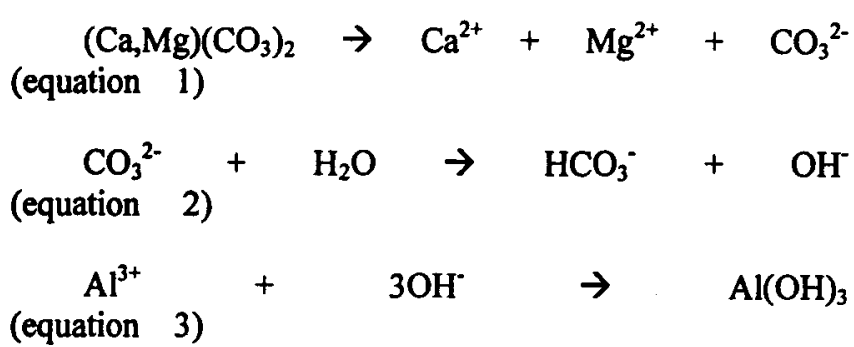

The GML dissolved readily on applying it into the acidic soil, releasing $\mathrm{Ca}$ and $\mathrm{Mg}$ (equation 1 ), and these macronutrients could be taken up the growing rice plants. Subsequently, hydrolysis of $\mathrm{CO}_{3}^{-}$(equation 2) would produce hydroxyls that neutralized $\mathrm{Al}$ by forming inert gibbsite (equation 3). Soil $\mathrm{pH}$ increased significantly following reduction of exchangeable $\mathrm{Al}$ (Figure $3 \mathrm{~A}$ ).

Calcium is by itself able to detoxify $\mathrm{Al}$ to certain extent (Alva et al., 1986). Hence, $\mathrm{Ca} / \mathrm{Al}$ ratio can be used as an index of soil acidity (Shamshuddin et al., 1991). Unfortunately, there was no correlation between rice and
$\mathrm{Ca} / \mathrm{Al}$ ratio in this study. Neither was there a correlation between relative yield and $\mathrm{Ca} / \mathrm{Al}$ ratio. However, there was an excellent correlation between $\mathrm{pH}$ and $\mathrm{Ca} / \mathrm{Al}$ ratio. This is shown by the equation in Figure 3B:

$\mathrm{pH}=0.19 \operatorname{Ln}(\mathrm{x})+4.36\left(\mathrm{R}^{2}=0.71\right)$

Figure 4 depicts the relationship between yield and relative yield with either exchangeable $\mathrm{Ca}$ or $\mathrm{Mg}$ in the acid sulfate soil. The correlation between yield and exchangeable Ca was poor, with low $R^{2}$ value (Figure $4 A$ ). The Pearson Correlation Coefficient was 0.32 with probability of 0.058 . Thus, the relationship between the two parameters was significant at $5 \%$ level. The same is true for the correlation between relative yield and exchangeable $\mathrm{Ca}$ (Figure 4B). As the relationship is poor, it is unable to determine the critical exchangeable $\mathrm{Ca}$ for rice cultivation on this particular acid sulfate soil. Nonetheless, there is indication that rice yield improves on GML application.

Further indication of the improvement of rice yield due to GML application is shown in Figure $4 C$ and $4 D$, where yield and relative yield, respectively when exchangeable $\mathrm{Mg}$ was increased.

Table 3. pH and the Exchangeable Cations ( $\mathrm{Al}, \mathrm{Ca}, \mathrm{Mg}$. $\mathrm{K}$ ) of the Topsoil after the Second Harves (May 1, 2004)

\begin{tabular}{|c|c|c|c|c|c|}
\hline \multirow[t]{2}{*}{ Treatment } & \multirow{2}{*}{$\begin{array}{l}\text { pH } \\
\text { water } \\
1: 2.5\end{array}$} & Al & $\mathrm{Ca}$ & $\mathbf{M g}$ & $\mathbf{K}$ \\
\hline & & \multicolumn{4}{|c|}{$(\mathrm{cmol} / \mathrm{kg})$} \\
\hline $\mathrm{Tl}$ & $3.95^{\circ}$ & $12.75^{\bullet}$ & $1.58^{e}$ & $0.48^{r}$ & $0.41^{\circ}$ \\
\hline $\mathbf{T 2}$ & $3.99^{\circ}$ & $10.22^{\mathrm{bb}}$ & $1.99^{d k}$ & $0.57^{\circ}$ & $0.24^{b x}$ \\
\hline T3 & $4.06^{\mathrm{d}}$ & $9.45^{\mathrm{bb}}$ & $2.22^{\infty}$ & $0.70^{d}$ & $0.15^{\mathrm{d}}$ \\
\hline $\mathrm{T} 4$ & $4.35^{\mathrm{b}}$ & $3.13^{\circ}$ & $2.81^{b}$ & $0.93^{b}$ & $0.19^{\text {bod }}$ \\
\hline T5 & $4.52^{\circ}$ & $2.37^{\circ}$ & $3.74^{*}$ & $1.10^{\circ}$ & $0.17^{+4}$ \\
\hline T6 & $4.21^{\mathrm{bc}}$ & $8.79^{a b}$ & $2.57^{b c}$ & $0.79^{\circ}$ & $0.27^{b}$ \\
\hline $\mathrm{T} 7$ & $4.16^{\mathrm{od}}$ & $7.46^{\mathrm{bc}}$ & $2.47^{b c}$ & $0.78^{\text {od }}$ & $0.21^{\mathrm{kod}}$ \\
\hline $\mathrm{LSD}_{0.05}$ & 0.14 & 5.15 & 0.47 & 0.08 & 0.08 \\
\hline
\end{tabular}

Means followed by the same letter within a column are not significantly different (LSD's test, $P<0.05$ )

Table 4. The Rice Yield at the First and Second Harvest

\begin{tabular}{|c|c|c|}
\hline Treatment & $\begin{array}{c}\text { First harvest } \\
\text { April 26, 2003 } \\
\text { (t/ha) }\end{array}$ & $\begin{array}{l}\text { Second harvest } \\
\text { May 1, 2004 } \\
\text { (tha) }\end{array}$ \\
\hline $\begin{array}{l}\mathrm{T} 1 \\
\mathrm{~T} 2 \\
\mathrm{~T} 3 \\
\mathrm{~T} 4 \\
\mathrm{~T} 5 \\
\mathrm{~T} 6 \\
\mathrm{~T} 7 \\
\end{array}$ & $\begin{array}{l}4.5^{\mathrm{bb}} \\
5.0^{\mathrm{a}} \\
3.5^{\mathrm{bc}} \\
4.4^{\mathrm{bcc}} \\
4.2^{\mathrm{bcc}} \\
3.7^{\mathrm{bc}} \\
3.1^{\mathrm{c}} \\
\end{array}$ & $\begin{array}{l}5.1^{k c} \\
4.5^{c} \\
6.3^{\star c} \\
6.6^{b} \\
7.2^{\star} \\
7.5^{a} \\
6.8^{b}\end{array}$ \\
\hline $\mathrm{LSD}_{0.05}$ & 1.4 & 2.0 \\
\hline
\end{tabular}

Means followed by the same letter within a column are not significantly different (LSD's test, $P<0.05$ ) 
A

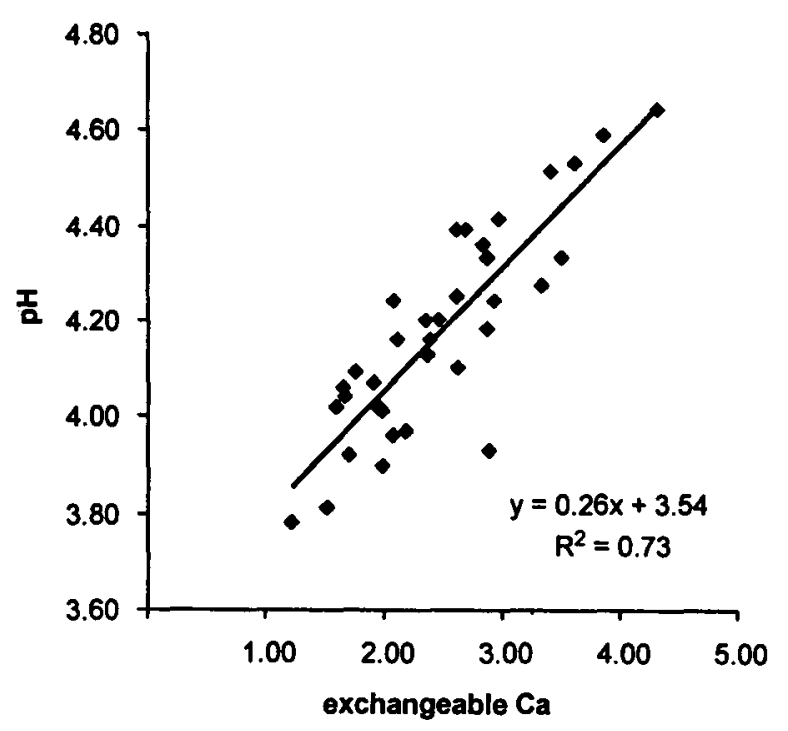

B

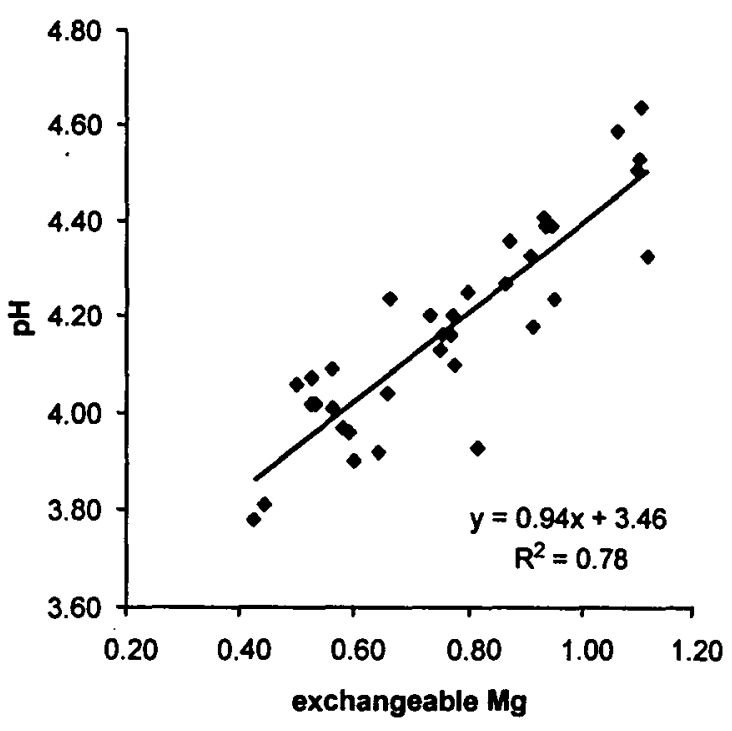

Figure 2. Relationship between $\mathrm{pH}$ and Exchangeable $\mathrm{Ca}(\mathrm{A})$ and $\mathrm{pH}$ and Exchangeable $\mathrm{Mg}(\mathrm{B})$ for the Second Season.

A

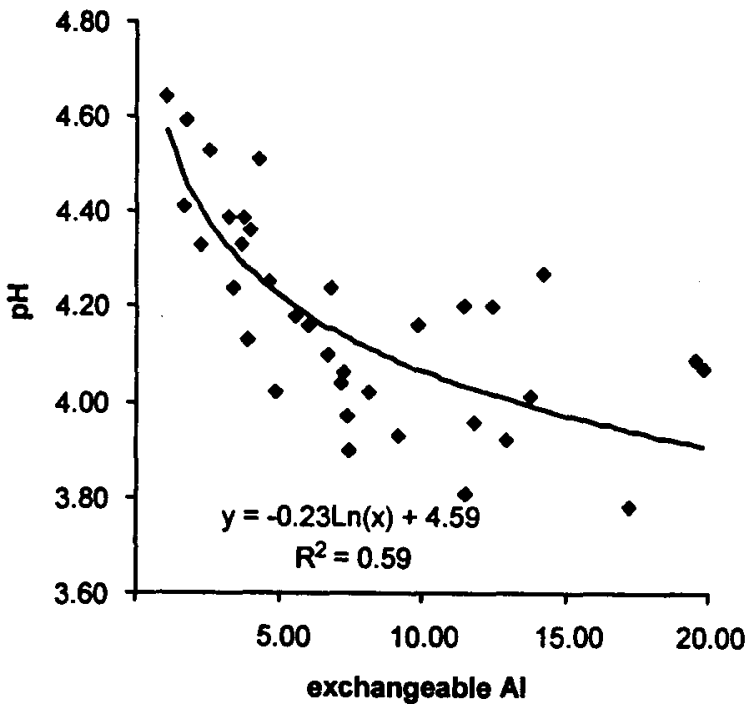

B

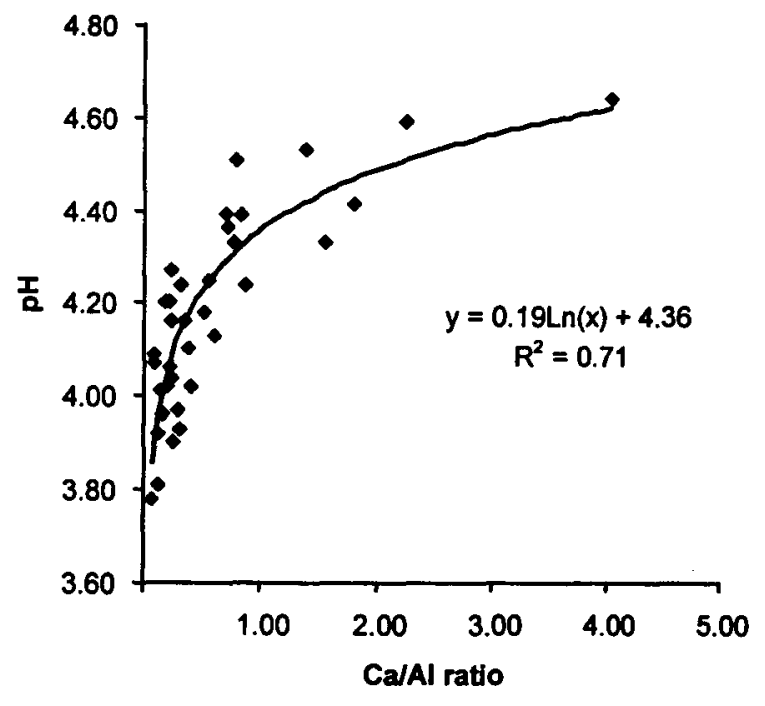

Figure 3. Relationship between $\mathrm{pH}$ and $\mathrm{Al}(\mathrm{A})$ and $\mathrm{pH}$ and $\mathrm{Ca} / \mathrm{Al}(\mathrm{B})$ Ratio for the Second Season 
A

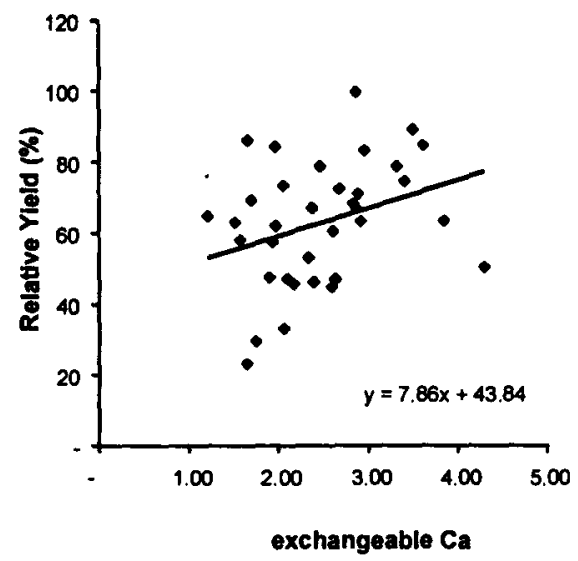

B

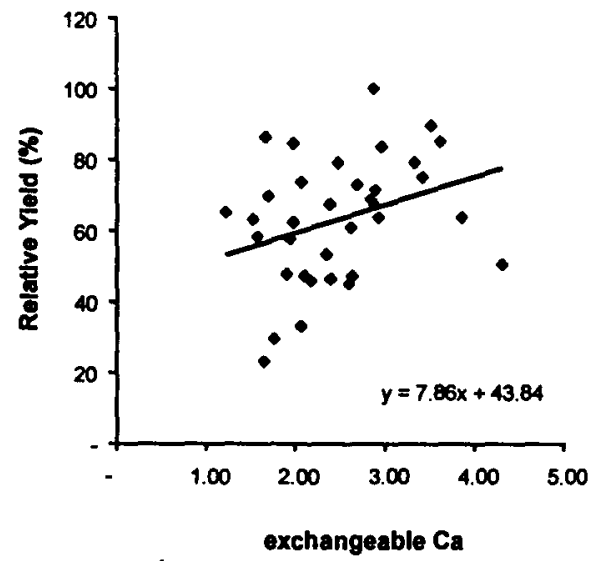

C

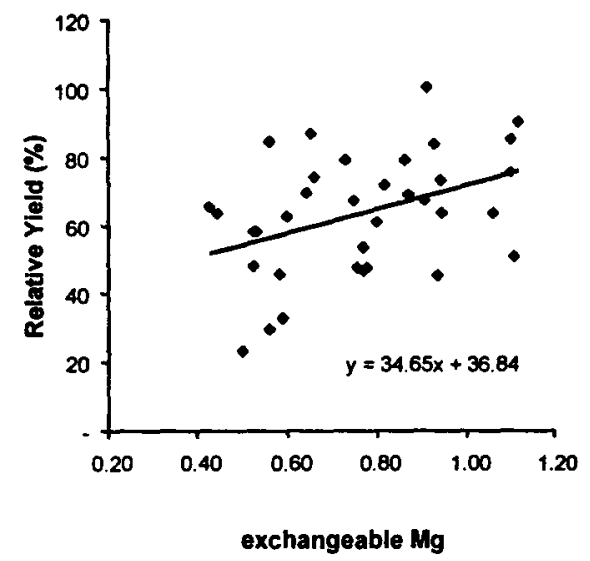

D

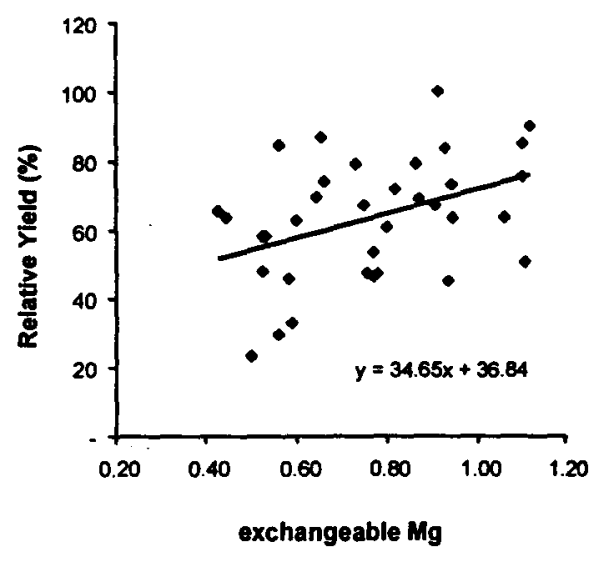

Figure 4. Relationship between Rice Y ield and Exchangeable $\mathrm{Ca}(\mathrm{A})$, Relative Yield and Exchangeable $\mathrm{Ca}$ (B), Yield and Exchangeable $\mathrm{Mg}(\mathrm{C})$ and Relative Yield with Exchangeable $\mathrm{Mg}(\mathrm{D})$ for the Second Season. $\left(\mathrm{R}^{2}<0.01\right)$

\section{CONCLUSION}

Using ground magnesium limestone and organic fertilizer (rice husk-based) at appropriate rate, rice cultivated on acid sulfate soils can produce yield comparable to that of the granary areas of Malaysia. This result of this study showed that rice yield could be as high as 7.5 tha using current technology, applying $4 \mathrm{t} \mathrm{GML/ha}$ in combination with an organic fertilizer.

\section{ACKNOWLEDGENTS}

The authors would like to thank Universiti Putra Malaysia and the Ministry of Science, Technology and Innovation Malaysia for financial and technical support.

\section{REFERENCES}

Alva, A.K., C.J. Asher and D.G. Edwards. 1986. The role of calcium in alleviating aluminum toxicity. Aust. $J$. Soil Res. 37: 375-383.

Arulando, X. and S.P. Kam. 1982. Management of acid sulfate soils in the Muda Irrigation Scheme, Kedah, Peninsular Malaysia. In $\mathrm{H}$. Dosh and $\mathrm{N}$. Breemen (eds). International Institute for Land Reclamation and Improvement. Volume 31, ILRI Publication. Wageningen, The Netherlands: p: 195-212.

Dent, D.L. 1986. Acid Sulfate Soil: A Baseline for Research and Development. International Institute for Land Reclamation and Improvement. Volume 39, ILRI Publication. Wageningen, The Netherlands.

Djia, H.D. 1973. Geomorphology. In D.S. Gobbet and C.H. Hutchison (eds). Geology of the Malay Peninsula. John Wiley \& Sons, New York. p: 13-24. 
Dobermann, A. and T. Fairhurst. 2000. Rice: Nutrient Disorders and Nutrient Management. Phosphate Institute of Canada and International Rice Research Institute, Los Banos, The Philippines.

Hoyt, P.B. and R.C. Turner. 1975. Effects of organic materials added to very acid soil on $\mathrm{pH}$, aluminum, exchangeable bases, ammonium, and crop yield. Soil Sci. 119:227-237.

Hue, N.V. and I. Amien. 1989. Aluminum detoxification with green manures. Commun. Soil Sci. \& Plant Anal. 20: 1499-1511.

Husson, O., P.H. Verburg and Mai Thanh Phunh. 2000. Special variability of acid sulfate soils in the Plain of Reeds, Mekong Delta, Vietnam. Geoderma 97: 1-19.

Moore,P.A. and W.H. Patrick. 1993. Metal availability and uptake by rice in acid sulfate soils. In D.L. Dent and M.E.F. Mensvoort (eds). International Institute for Land Reclamation and Improvement. Volume 53, ILRI Publication. Wageningen, The Netherlands: p: 205224.

Muhrizal, S., J. Shamshuddin, I. Fauziah,I. and M.H.A. Husni. 2003. Alleviation of aluminum toxicity in acid sulfate soils in Malaysia using organic materials. Commun. Soil Sci. \& Plant Anal. 34: 2999-3017.

Muhrizal, S., J. Shamshuddin, I. Fauziah and M.H.A. Husni, 2006. Changes in an iron-poor acid sulfate soil upon submergence. Geoderma 131:110-122.

Nhung, M.M. and F.N. Ponnamperuma. 1966. Effects of calcium carbonate, manganese dioxide, ferric hydroxide and prolonged flooding and electrochemical changes and growth of rice on a flooded acid sulfate soil. Soil Sci. 102: 29-41.

Ooi, J.B. 1964. Land, People and Economy of Malaya. Longmans; London.

Palhares, M. Recommendation for fertilizer application for soils via qualitative reasoning. J. Agric. Sys. 67: 21-30.
Ponnaperuma, F.N., T. Attanandana and G. Beye. 1973. Amelioration of three acid sulfate soils for lowland rice. In $\mathbf{H}$. Dash (ed). International Institute for Land Reclamation and Improvement. Volume 18, ILRI Publication. Wageningen, The Netherlands: p: 391406.

Rorison, I.H. 1973. The effects of extreme soil acidity on nutrient uptake and physiology of plants. In $\mathrm{H}$. Dosh (ed). International Institute for Land Reclamation and Improvement. Volume 18, ILRI Publication. Wageningen, The Netherlands: p: 223-254.

Shamshuddin, J., I. Che Fauziah and H.A.H. Sharifuddin. 1991. Effects of limestone and gypsum application to a Malaysian Ultisol on soil solution and yields of maize and groundnut. Plant and Soil 137: 45-52.

Soil Survey Staff. 1999. Soil Taxonomy: A Basic Soil Classification for Making and Interpreting Soil Surveys. USDA, Natural Resources Conservation Services, Washington, DC, 1999.

Soo, S.W. 1975. Semi-detailed Soil Survey of Kelantan Plain. Ministry of Agriculture \& Rural Development, Kuala Lumpur.

Ting, C.C., S. Rohani, W.S. Diemont and B.Y. Aminuddin. 1993. The development of an acid sulfate soil in former mangroves in Merbok, Kedah, Malaysia. In D.L. Dent and M.E.F (eds). International Institute for Land Reclamation and Improvement. Volume 53, ILRI Publication. Wageningen, The Netherlands: p: 95-101.

Tran, K.T. and T.G. Vo. 2004. Effects of mixed organic and inorganic fertilizers on rice yield and soil chemistry of the $8^{\text {th }}$ crop on heavy acid sulfate soil (Hydraquentic Sulfaquepts) in the Mekong Delta of Vietnam. A paper presented at the $6^{\text {th }}$ International Symposium on PlantSoil at Low pH. August 1-5, 2004; Sendai: Japan.

Wakley, A. and I.A. Black. 1934. An examination of the Degtjrref Method for determining organic matter, and a proposed modification of chromic acid titration method. Soil Sci. 37: 29-38. 